\title{
Protected Areas and Sustainable Development: A Chance for Biodiversity or a New Self-Deception
}

\author{
Evgeny A. Shvarts' and Alexander S. Shestakov ${ }^{2}$ \\ 1 Director of Conservation, World Wide Fund For Nature, Russian Programme Office \\ 2 Environment Law Officer of WWF Russian Programme Office \\ 19, Nikoloyamskaya Str., bd. 3, RU-109240 Moscow, Russia \\ E-mail: eshvarts@wwf.ru, ashestakov@wwf.ru
}

\section{Introduction}

The Russian Federation has a unique and highly developed system of especially protected nature reserves and is in many respects a pioneer in realising the concept "from islands to econets" (SOBOLEV et al. 1995; OSTERGREN and ShVArts 1998; Sittler et al. 2000). The nucleus of the ecological network in Russia encompasses: 1) federal protected areas - first of all strict nature reserves (zapovedniks; IUCN category I) and national parks (IUCN category II); 2) regional protected areas of the subjects of the Russian federation (altogether about 15,000, 111.5 millions ha) - first of all sanctuaries, nature parks, natural monuments (IUCN categories II-V); and 3) various categories of protected forests (altogether 271 millions ha forest grounds, 180.6 millions ha of which are covered with forests).

Today, in the Russian Federation, 99 strict nature reserves exist with a total area of more than 33 millions ha, of which 26 millions ha on land area with inland waters $(1.56 \%$ of the entire territory of the Russia Federation). The reserves are located in 65 of the 89 federal regions. Most reserves (93) were directly supervised by the State Committee for Environmental Protection, four are managed by the R ussian Academy of Sciences, one by the Federal Forest Service, and one by the Ministry of Higher Education. A ccording to current legislation the state reserves have a status of environmental research organisations, with a staff of about 5000 people. Prominent Russian naturalists established this nation-wide system of zapovedniks more than 80 years ago.

The first national park was founded in 1983, and today in Russia 35 national parks exist with a total area of more than 6.7 millions ha; all of them were managed by the Federal Forest Service.
The originality of the Russian nature reserves and national parks system and its high relevance for preserving the natural heritage and biodiversity are recognised all over the world.

$22 \mathrm{R}$ ussian zapovedniks received the status of biosphere reserves of the UNESCO, eight zapovedniks and three national parks fulfil the requirements of the Convention on the Protection of World Cultural and Natural Heritage, ten nature reserves and one national park is part of the Ramsar convention (Convention on Wetlands of International Importance especially as Waterfowl Habitat), four reserves received diplomas from the Council of Europe.

On 17 May 2000, owing to the structural reorganisation of the Russian Government, the main purpose of which is to continue the economic reforms and to improve the climate for investments in Russia, the president of the Russian Federation V.V. Putin issued a decree about the abolishment of the State Committee for Environmental Protection and the Federal Forest Service. These two institutions were responsible for most federal protected areas (nature reserves and national parks) and provided methodological support for most protected areas created by regional administrations. All functions of these institutions were transferred to the Ministry of Natural Resources, previously responsible for mineral and water resources. In the past two years the ministry violated in four cases the protected area legislation: illegal prospecting and mining of gold on the territory of "Yougyd-Va" national park (republic of Komi) as well as in the protected zone of Kurilsky nature reserve (Kunashir island), illegal prospecting for petroleum on the territory of sanctuaries in the Saratov region, and construction of the Youmagusincky water reservoir, in the "Bashkirjya" national park without previous state environ- mental review at federal level. The Ministry of Natural Resources lost almost every case against the Committee for Environmental Protection. The abolishment of the Committee for Environmental Protection and the Federal Forest Service enables the Ministry of Natural Resources to increase the number of its own mineral and water services and to reduce or abolish the environmental services. First of all this concerns the regional services, which due to their great number up to now have been able to oppose illegal economic activities on the regional level. The result of this may be sinking protection standards, reduction or even abolishment of the protected area system, for example, by putting zapovedniks under the direct control of regions. These circumstances will make it more difficult to consolidate and develop the protected area system by establishing an "econet" or "ecological framework", considered by specialists as a key element of sustainable development.

We observe a dangerous pattern in our country: every time when our country begins to recognise the limits of an economical development that goes with the exten sive exploitation of natural resources, protected areas become increasingly threatened. In 1951, pressure of the Ministries responsible for exploitation of natural resources (primarily Ministry of Forestry) resulted in the elimination of 20 out of 33 existing state reserves. In 1961, as soon as the nature reserve system was partly restored under Chrushov, the next set of nature reserves was closed. But it was obvious, that eliminating nature reserves, the area of which is insignificant compared to the area of the whole country, couldn't change the fact that extensive development was limited. Looking for a more effective way of intensive development, Chrushov established the famous "Sovnarchosy" (re- 
gional economical management authorities), that were similar (as regards the territory) to the "federal districts" recently established by V.V.Putin. But because of the strong resistance inside the old structures, the reforms of Chrushov failed, as did later the reforms of A.N. Kosygin and many others.

The present situation in Russia reflects the opinion of many economists that only an economically prosperous country is able to preserve biodiversity and observe high environmental standards. Economic prosperity, in turn, can only be achieved by reducing the environmental standards. In other words: in order to preserve nature we first have to "destroy" it, and the part we destroy has to be bigger than the part left for protection. The fact that the Netherlands, the main supporter of wildlife protection projects in Russia (the second or third important donor for environmental projects on the governmental front and the most or second important donor for such projects on the non-governmental front) is one of the most severely transformed territories of the world, seems to support these economists. In Great Britain where the market shows the highest "ecological sensitivity" (up to $200575 \%$ of the whole wood market will be certified according to the standards of the Forest Stewardship Council, FSC) practically no natural forests are left, and common dormouse is the "flagship species" in the protection of biodiversity. It's no wonder that this approach is fully supported by the Russian petroleum and gas industry which is also convinced that the abolishment of state environmental reviews (also a duty of the abolished State Committee for Environmental Protection) and ecological control of petroleum and gas production would increase the economic prosperity of Russia.

Nevertheless, the past 17-18 years of the former Soviet Union contradict this concept. During this period the whole economy of the country relied on the export of petroleum and gas, which thanks to high petroleum prices on the world market somehow supported the extensive, extremely ineffective economy that lead to the current ecological situation in Russia. To be fair, it has to be said that in the former Soviet Union neither existed a Committee for Environmental Protection, nor the national environmental impact assessment, nor an independent legal system or independent nongovernmental organisations (except for student nature conservation corps (Druzhina) movement). The system collapsed when the United States, Western Europe and the OPEC countries increased the output of petroleum severely reducing the demand for mineral oil from Russia. The Soviet Union, as well as now Russia, was virtually excluded from the decision-making process.

However, the question arises whether or not, economic development is possible without destroying the ecology of large areas. In the next chapter we will try to answer this question.

\section{Is it theoretically poss- ible to preserve a system of protected areas under the conditions of inten- sive economic develop- ment?}

The economic crisis in all countries of the former Soviet Union, and the disappearance of the Soviet middle class, have reduced the significance of all questions connected with environment protection, especially with regard to biodiversity. The weakening of the federal authority and the national planning, forced most administrative regions in the Russian Federation "to act locally". In other words, each administrative region must provide for its own economical development, mostly following the traditional path to industrialisation. Obviously, for every region this means repeating the development of the Western countries. This process, of course, entails the transformation and fragmentation of undisturbed and lightly disturbed natural areas. It is doubtful whether this will lead to economic wellbeing, at least, if judging from the ever increasing difference in living standard between the developed countries and the majority of underdeveloped countries (with the exception of some petroleum exporting countries). Some decades ago was shown that the relative stable balance of carbon dioxide output and oxygen input on the territory of the United States and other developed countries is more and more provided by natural territories in underdeveloped countries; to date this estimations haven't been denied.
Consequently, the resources of biosphere are not sufficient to support a Western-style economic development in all the countries of the world.

One of the main causes of the disappearance of animal and plant species is fragmentation and transformation of their habitat. The disappearance of many species, especially large animals such as the lynx, brown bear, wolf, etc., as a direct consequence of the fragmentation of natural areas and ecosystems has frequently been observed in Western Europe. In Sweden, for instance, it was shown that the wolf had disappeared completely in those parts of country, where the density of roads exceeds a certain threshold. Small nearto-natural in an island urbanised and agriculturally extensively utilised landscape cannot withstand the "ecotonisation" of the species composition and prevent the theoretically possible blockade of natural successions by weeds and introduced species. This could lead to a "global biotic crisis" (BARSKOv et al. 1993; VAKHRUSHEV and R AUTIAN 1993).

Retracing the development of the industrialised countries leaves little hope for the preserving of many species of living organisms, first of all, those which need large undisturbed areas, in countries of Northern Eurasia with transitional economies and developing countries in tropical territories. A basic, potential way to avoid this unfortunate scenario is to spatially separate areas of intensive economic development from the undisturbed territories. The countries of the Commonwealth of Independent States (CIS), first of all Russia, can theoretically not only protect natural areas (which are practically absent in Western Europe, but exist along with semi-natural and highly developed industrial areas in the CIS), but also create economic and socio-political mechanisms leading to the spatial segregation of industrial and natural sites. The need to create such mechanisms is dictated in the first place by the fact that if each administrative region of the Russian Federation sets out on its own independent path to extensive industrialisation, this would inevitably lead to the fragmentation of large natural areas of forests and marshes with the concomittant losses in biodiversity (largest amongst of mammals and bird species first of all species of upper levels of the food chain; various groups of animals, plants and fungi connected with old-growth forests and dead 
wood, etc.). The creation of mechanisms for spatial segregation in Russia have to be of great international interest, as the administrative regions of the Russian Federation correspond in size, population and economic potential to some Western European countries as well as countries in A frica and Latin America. This means that such mechanisms can be useful to many regions of the world.

The Pan-European Biological and Landscape Diversity Strategy, which is realised under the auspices of the Council of Europe, is probably the best macro-regional initiative for solving this problem. The task is to establish an ecological network. Within the confines of the Pan European Strategy, all countries of the Pan-European ecological network (including the states of Central A sia) pledged to plan and establish a such an ecological network by the year 2010. The establishment of the network is crucial for preserving areas of high biodiversity and in order to ensure their protection under one single system. This system includes: core areas, buffer zones, connecting corridors, and zones of ecological rehabilitation and restoration.

Moscow geographer B.B. Rodoman has developed "the landscape polarisation" theory, based on Walther Christaller's idea (CHRISTALler 1966) and his own observations mainly of the Moscow region. This theory is regarded as an universal mechanism for spatial separation of urban and protected natural areas, aimed at preserving biodiversity and recreational resources (RoDOMAN 1974). It includes a whole series of geographical and ecological principles, the most important of which is improved territorial structures for construction realistic ecological networks in already developed regions (Rodoman 1988). In the European part of Russia, the concept of "landscape polarisation" is particularly useful in the third stage of urbanisation, for example, in the centres of people and manufacturing are concentrated while in peripheral regions numbers and activities of man are reduced (for more details see GiBBS 1963; HaLl and HAY 1980; Pivovarov 1991). This concept leads to an ideal ecological network of natural protected areas (NPA), located on the borders of regions and divided only by roads which connect the regional centres in the shortest possible way. Thus, from the position of the preservation of biodiversity, the framework of natural areas and the ecological network of protected natural areas serve as a complimentary antipodes to urbanised areas. That is to say that it is potentially possible to turn around the state of the ecological network by means of "resistance" through the study of the spatial regularities of the distribution and dynamics of urban territories.

Almost twenty years after the publication of his theory, Rodoman unexpectedly began to doubt the validity of his theory after observing the massive development of urbanisations and especially the construction of cultivated tracts of land in the country. This doubt was expressed in an article under the telltale title: "Buried U topia or Prediction that came true?" (Rodoman 1993). Modelling the process of the evolution of settlements (kitchen-garden-garden association - summer home - winter home - few stories building towns future slums) Rodoman regards this process as a result of a poorly managed spatial development. There are notes of nostalgia for leaving times in his publication. "Cars make the urban agglomeration dispersed as the oil over the paper and owing to trains it is kept within the "stars rays" leaving the green spaces between them. We should not try to reach the states of Western Europe and Northern America of the day before yesterday. It is necessary to hold the traditional priorities in transport development - the public transport and the railway - and do away with privatisation of forest and flood-plain lands. Thus we will look after our natural areas of global importance in order to preserve this richness for the post-industrial society. It would be very regrettable to lose this splendid chance!" (RODOMAN 1993).

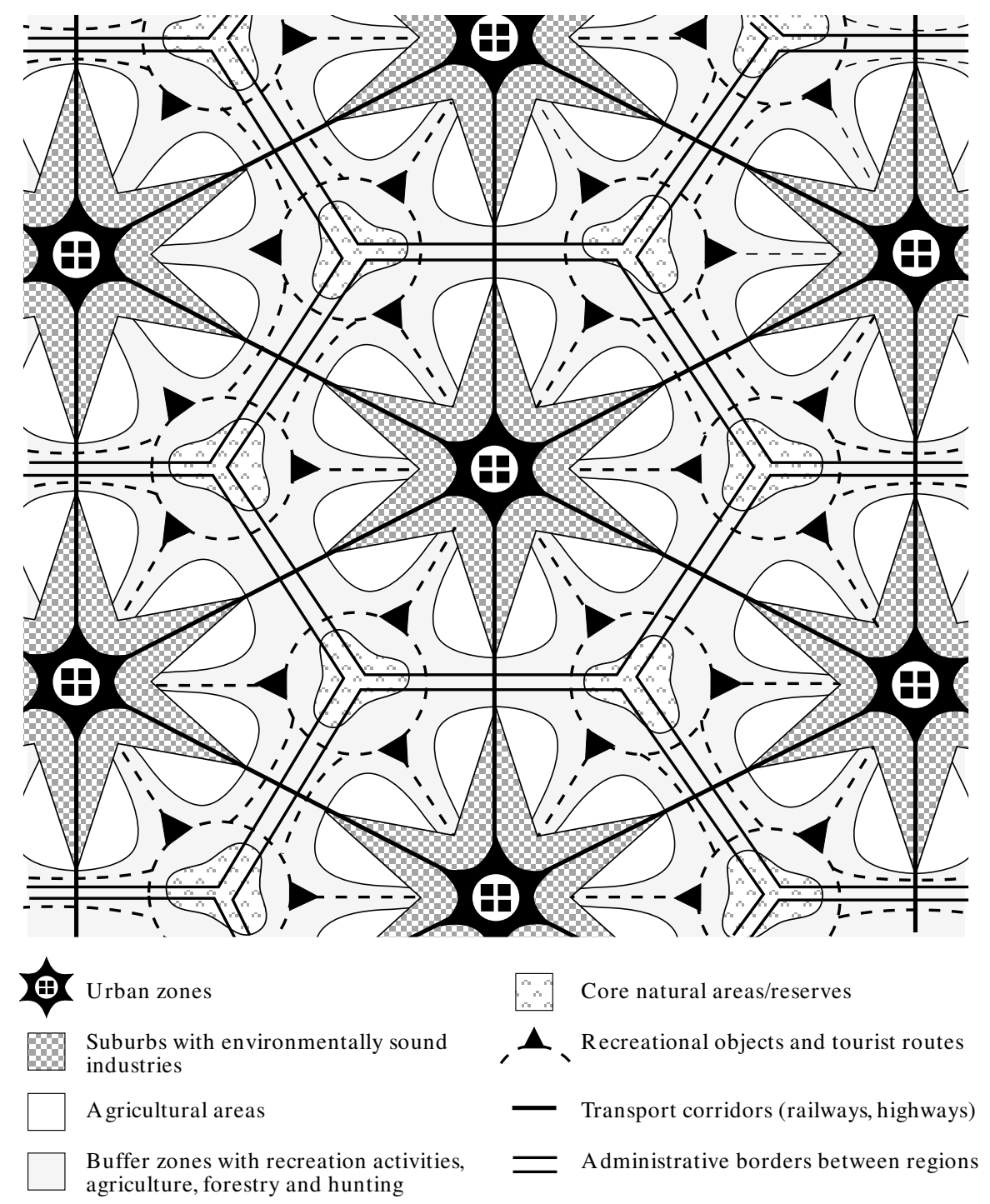

Fig. 1. Polarizated landscape (From B.B. Rodomann, 1977 with minor changes) 
In our opinion, it is the transition from third stage of urbanisation to the fourth stage (territorial growth of urban centres accompanied by the reduction of population and manufacturing in the peripheral regions) and perhaps even to the fifth stage (disurbanisation when the development of peripheral regions overtake the one of the center), taking place in the area between Moscow and Saint-Petersburg, which makes Rodoman doubt the prognostic values his theory ("Buried Utopia"). It is no coincidence that Rodoman pays special attention to the region located in the Northwest of Moscow (Rodoman 1991). On the other hand, it is hardly possible to artificially limit the number of cars used in an area. Although the urbanisation objective laws are not referred to in Rodoman's articles, it is obvious that the concept of the "polarised landscape" corresponds to the third stage of urbanisation. As the fifth stage of urbanisation begins the polarised landscape is inevitably destroyed (SHVARTS and Sobolev 1995), as we can see in the Western Europe.

Since the growth of urban agglomerations (the fourth stage of the urbanisation) and the subsequent disurbanisation (even distribution of the population on the fifth stage of the urbanisation) appear to be the normal stages urban development, the question arises whether the ecological network (ECONET) is not just another utopian fantasy. Will ECONET really give a chance for preserving the natural biodiversity - or is it not just another selfdeception of unrealistic intellectuals and hopeless conservation romantics?

Let us analyse the difference between the laws governing Nature and the areas ruling Society in order to answer the question mentioned above. The main difference is that the discovery of natural laws does not change nature, while the description of the social science law inevitably changes society, for example, the subject of study itself. For example, the description of the objective laws of the population dynamics of small terrestrial mammals in the main scientific journals can not modify these laws because shrews and voles do not read journals. By contrast, the description of social laws inevitably modifies society. The publication on this matter influences scientists, social knowledge passes from them to journalists, politicians, the public at large.
Everyone takes into account in his everyday activities trying to avoid or, conversely, precipitate one or another consequence of the newly revealed social law, modifying thereby the society in the fields affected by that social law. In other words, Franklin Roosevelt was the best Marxist in comparison with many of those who named themselves like this.

The comparison of the spatial distribution of state nature reserves (zapovedniks) on the territory of the former USSR (ShVARTs et al. 1996) and the National Wilderness Preservation System (1987) in the USA taking into account the size and number of protected areas shows that, in both countries, the spatial distributions of the national NPAs are very similar, because of a similar colonisation history. In the olddeveloped regions (the European part of the former USSR, the Eastern coast of the USA) NPAs are large in number, but as a rule small in size. To the contrary, in the regions colonised last (the North of the European Russia, Siberia, Far East in the USSR, Western part of the USA) only few but very large NPAs exist.

Despite many historical and ideological differences between the systems of national NPAs in the USSR and the USA, the reasons for their similar distribution in space are clear. The idea of conserving wilderness areas appeared when in old-developed regions the lands were already cultivated and delimited between land-users, but vast natural tracts in the not yet colonised regions still existed. These vast natural tracts became the zapovedniks in the USSR and, respectively, national forests, national parks and other federally managed natural areas in the USA (BLINNIKov 1996).

Although the extent of the urbanisations in the Western part of the USA has increased dramatically during the last century, the sizes of the individual national forests and national parks were not reduced. Thus altered public consciousness modified the socio-geographic laws that existed before and revealed in old-developed regions. Hence, the analysis of spatial distribution of federally managed NPA in USA and former USSR warrants optimism: early establishment of natural reserves and sanctuaries, and national parks in, at present, economically not yet attractive areas, and the creation of the ECONET (not only by means of preserving existing natural sites, but also via the ecological restoration of transformed and degraded areas, in particular, in forest-steppe and steppe zones of the former USSR) should allow the preserve in the long-term the full natural biodiversity and the natural areas of global importance.

In order to implement this plan the co-operation of all the social forces and sectors is needed. Economical mechanisms corresponding to those which resulted in the creation of ECONET should be established in the former USSR. This, in particular, because ECONET competes not only with country houses but also with ecologically hazardous industries which will be moved out of the urban areas. Linear communications such as the Moscow Capital Beltway (MCB). High Speed Railway Moscow-Saint-Petersburg, new surface pipelines present severe problems, likely to become more severe in the future. They should be built taking into account that: "Although, in the polarised landscape, Nature and city have equal rights, we should treat Nature as the weak partner and give its precedence: the networks of natural parks should be retained uninterrupted while the network of settlements may be interrupted. Ideally, the green corridors and human transport should in fact be interlaced, that is to crossing at different levels: ravines, trespasses, underground-passages for animals". (Rodoman 1993). Unfortunately, all these ideas were not implemented when the Moscow capital beltway (motorway) was constructed, interrupting the connection between the relatively large semi-natural areas of Moscow and its natural surrounding - the green rays of the Moscow forestparks belt.

Many large undisturbed natural areas have to be included into ECONET. At the same time they play a vital role in maintaining global ecological balance of biosphere. It is necessary to work out the economic relations between ECONET and measures against the climate changes as carbon dioxide credits and other similar international economic initiatives. Separate and uncoordinated implementations of these initiatives may hurt the conservation of biodiversity - for example, the logging of old-growth taiga or plantation of new forest on the last remnants of steppe.

Active Russian participation in the establishment of global economical 
mechanisms and incentives for preserving biodiversity and, particularly, in the implementation of the PanEuropean Biological and Landscape Diversity Strategy offers for Russia the possibility to attain a principally new position place in the global community. Having not only enormously large pristine natural areas but also a huge economic potential, Russia is one of the few countries that can work out and realise on its own territory spatial segregation of the natural areas the industrially developed regions at a large scale. In doing so conservation of the natural heritage of Russia should become a crucial element of the new national identity.

\section{International aspects of maintaining protected natural areas as el- ements of a sustainable development; the Altai- Sajansky Initiative}

It's obvious that preserving the unique biodiversity in the eco-regions of Russia is of great importance not only for R ussia. It's also obvious that today most areas that are in urgent need of protection are located predominantly outside the highly developed countries. With the map "Global 200" WWF accomplished a great work, listing regions that together would allow to protect between 90 and $95 \%$ of all species of the world. In the current economic situation, especially considering the shortterm interests of politicians and decision-makers, traditional efforts of coupling economic development with a sustainable use of the renewable natural resources have to give way to programs that are leading to irreversible transformations, industrialisation and fragmentation of ecologically highly diverse regions. All over the world, political leaders consider the ecological standards designed by the developed countries, as an obstacle to the necessary economic development, discriminating their countries against the developed world. Even considering that their arguments are not always valid they touch a very serious problem, on which are based the demands of ecologicalorganisations to the World Trade Organisation (WTO).

In October 1999, the governors of five Russian regions and four Mongo- lian ajmags, together with leaders from Russian and Mongolian WWF Program Offices, issued the Altai-Sajansky initiative (named after one of the Global200 Ecoregions of global biodiversity importance; this transboundary ecoregion cover the territories of Russia, Mongolia, Kazakhstan and China). The text of the initiative is given in appendix 1. Subsequently, the Republic of Kazakhstan and another three subjects of Russian Federation namely Republic of Komi, Republic of Adygey and Kemerovo oblast joined the Initiative.

The initiative deals with economic mechanisms, and not with financial ones. We don't suggest that the developed countries are responsible for the preservation of natural areas in the underdeveloped countries or to double the activity of Global Environment Facility. We propose to establish a system of economic mechanisms that provides incentives for an economically highly efficient production in conditions of sustainable development in important eco-regions. That could be for example, special measures of the WTO, a policy of supporting projects of organisations like the World Bank or $\mathrm{ABRD}$, a practice of certifying according to FSC.

As a first step toward the realisation of the Altai-Sajansky Initiative we plan to issue a special protocol to the Convention on Biological Diversity, similar to the Kiotsky protocol to the UN Framework Convention on Climate Change. We expect this protocol to be a practically orientated supplement to the Convention on Biological Diversity.

The main items of the Altai-Sajamsky initiative were previously presented to the world community during the meetings of the Subsidiary Body of Scientific, Technical and Technological Advice (SBSTTA-5, Montreal), as well as at the Conference of Parties (COP-5, Nairobi) of the Convention on Biological Diversity (CBD). Some items and ideas of the initiative entered into the decisions of the COP-5: V/6 "Ecosystem approach", V/15 "Incentive measures" and V/24 "Sustainable use as a cross-cutting issue". The initiative was discussed with delegates from several countries and, on the whole, was supported by them.

However, in the course of the discussions we met some problems and difficulties that have to be taken into account in our further work:
1. Many countries are not willing to designate eco-regions for the preservation of biodiversity.

2. Many countries, especially small European countries such as the Netherlands don't agree with the term "eco-region".

3. Some countries (for example, Brazil) don't agree with the idea of transnational protection of biodiversity and insist that national sovereignty over natural resources has to be fully recognised. However, they recognise the possibility and need of international partnership.

4. To be able to develop economic mechanisms stimulating the preservation and rational use of biodiversity we first have to define what biodiversity is and how it can be assessed (for example, by its monetary value).

5. Some principles of the initiative (for example, tax benefits for trading with products that were produced using traditional methods in priority ecoregions) may contradict regulations of the WTO.

In conclusion, the spatial separation of regions with intensive economic development and regions where biodiversity and traditional extensive land-use are preserved can serve as basis for sustainable development in macro-regions (Russian Federation) and in the whole world.

\section{Acknow ledgements}

It is a pleasure to express my thanks to Mrs. Brigitte Steiger, Swiss Federal Institute for Forest, Snow and Landscape Research, for assisting with the translation of the manuscript.

\section{References}

BARSKOV, I.S.; ZhYERIKHIN, V.V.; R AUTIAN, A.S., 1996: Problems of the biodiversity evolution (Barskov, I.S.; Žèrihin, V.V.; Rautian, A.S. problemy ėvolûcii biologičeskogo raznoobraziâ. Žurnal obščej biologii 57, 2: 14-39. - in Russian).

BLINNIKOv, M.S., 1996: Nature conservation in USA: the short text-book for probationers (Blinnikov, M.S. Likbez po ohrane prirody v SŠA: posobie dlâ stazërov. M.: Centr ohrany dikoj prirody. 68 pp. - in Russian).

Christaller, W., 1966: Central Places in Southern Germany. Prentice-Hall, Englewood Cliffs, N.J. 
GibBs J., 1963: The evolution of population. Econ. Geography 39, 2: 119-129.

HALL, P.; HAY, D., 1980: Growth centres of the European urban system. London: Heinemann. 278 pp.

Ostergren,D.;Shvarts, E., 1998: Protected areas in Russia: designation, management goals, current status, and future prospects of Russian Zapovedniki (Strict nature preserves). Personal, Societal, and Ecological Values of Wilderness: Sixth World Wilderness Congress Proceedings on Research, Management, and Allocation, Volume I. 11-19.

Pivovarov, Yu.L., 1991: Spatial evolution of the urbanisation: some stages of the development (Pivovarov Û.L. Prostranstvennaâ ėvolûciâ urbanizacii: nekotorye rubeži razvitiâ. Prostranstvennoe razvitie urbanizacii: obščie zakonomernosti i regionalnye osobennosti. - M.: institut geografii AN. 5-25 - in Russian).

Rodoman, B.B., 1974: Landscape polarisation as a means of keeping biosphere and recreation resources (Rodoman, B.B. Polârizaciâ landšafta kak sredstvo sohraneniâ biosfery i rekrefcionnyh resursov - resursy, sreda, rasselenie. M., 150162 - in Russian).

RoDOMAN, B.B., 1988: Ecological principles of the improvement of the Moscow re- gion territorial structure (Rodoman, B.B. Ėkologičeskie principy soveršenstvovaniâ territorialnoj struktury Moskvy i Podmoskovâ - Moskovskij stoličnyj region. Voprosy geografii 131.-M.: Mysl, 72-79. - in Russian).

Rodoman, B.B., 1991: North-West border of the Moscow-City and the development of town of Zelenograd (Rodoman, B.B. Severo-zapadnaâ granica Moskvy i razvitie Zelenograda - Prostranstvennoe razvitie urbanizacii: obščie zakonomernosti i regionalnye osobennosti. M.: institut geografii RAN. 141-149 - in Russian).

Rodoman, B.B., 1992: Buried Utopia or Prediction that came true? (Rodoman, B.B. Pohoronennaâ utopiâ ili opravdavšijsâ prognoz? Znanie - sila" 5. - in Russian).

Rodoman, B.B., 1993: Introduction to the social geography. (Rodoman, B.B.Vvedenie v socialnuû geografiû. Kurs lekcij. M.: Rossijskij otkrytij universitet $\mathrm{i}$ institut geografii RAN. 78 pp. - in Russian).

Shvarts, E.A.; Sobolev, N.A., 1995: The spatial dynamics of modern landscapes and problems of biodiversity conservation in the central part of European Russia Research in eastern Europe to solve nature conservation problems in the Nordic countries. Uppsala: Swedish University of
Agricultural Sciences. Dept. of Wildlife Ecology. Rapport 28: 57-58 and 113-114.

Shvarts, E.A.; Cheifets, O.A.; Morozova, O.V.; Volkov, A.E.; Kozharinov, A.V.; Krever, V.G.; Lysenko, I.G.; PUShKaryov, S.V., 1996: Species richness of terrestrial vertebrates and higher plants in the state zapovedniks of the former USSR (Švarc, E.A.; Hejfec, O.A.; Morozova, O.V.; Volkov, A.E.; Kozarinov, A.V.; Krever, V.G.; Lysenko, I.G.; Puškarev, S.V. Vidovoe bogatstvo nazemnyh pozvonočnyh i vysših rastenij v gosudarstvennyh zapovednikah byvšego SSSR. Uspehi sovremennoj biologii 116, 6: 645-672in Russian).

Sittler, B.;Tennhardt,T.;Shvarts, E.,2000: Protected Areas in Russia facing new challenges for the future. Nat. Landsch. 1: 1-9.

Sobolev, N.A.; Shvarts, E.A.; Kreindlin, M.L.; MokievskiY, V.O.; Zubakin, V.A., 1995: Russia's Protected Areas: Base survey and identification ofdevelopment problems. Biodivers. Conserv. 4, 9: 964-983.

Vakhrushev, A.A.; Rautian, A.S., 1993: The historical approach to the community ecology. (Vahrušev, A.A.; Rautian, A.S. Istoričeskij podhod k èkologii soobščestv. Žurnal obščej biologii 54, 5: 532-553. in Russian). 


\section{Altai-Sayan Millennium Initative}

At the turn of the Millennium, assembled in the Altai-Sayan region, one of the centres of World Civilisation with a unique natural and cultural heritage and one of the 200 priority eco-regions of the Planet,

We, the undersigned

The Head of the Republic of Altai (Russia),

The Chairman of Government of the R epublic of Khakassia (Russia),

The President of the Republic of Tyva (Russia),

The Head of Administration of the Altai Territory (Russia),

The Governor of the Krasnoyarsk Territory (Russia),

The Governor of Bayan-Ulgii (Mongolia)

The Governor of Aimag Khovd (Mongolia)

The Governor of Aimag Khuvsugul (Mongolia)

The Governor of Aimag Uvs (Mongolia)

The Director of the WWF Russian Program Office

The Director of the WWF Mongolian Project Office

- DEEMING it necessary to bring forth a higher civilisation based on sound ecological principles, through building an ecological culture established on environmental values;

- ACKNOWLEDGING our responsibility to ensure for our peoples an adequate quality of life, comprising economic, environmental and social aspects;

- REALISING our responsibility to ensure that our children and future generations are not deprived of the wonderful gift of a living Planet and the deep wisdom embedded in its cultural heritage;

- BEARING IN MIND that we are living in the conditions of a changing climate and abiding by the decisions by the World community in Rio de Janeiro in 1992 and Kyoto in 1997 ,

- UNDERSTANDING that irrational exploitation of natural resources and the subsequent attempts to restore them cost immensely more than preservation of the initial natural harmony;

- REFERENCING the initiative of the Earth Charter, which stresses that Planet Earth is a living system and that we are only alive as long as our Planet lives;

- SUPPORTING the principle of selecting 200 eco-regions on the Planet as a priority for nature conservation and as a repository for the unique natural and cultural diversity of these eco-regions that should be passed on intact to the next Millennium and kept so forever;

- ACKNOWLEDGING the eco-region based conservation approach as a new principle based on natural boundaries.
Appeal to the world community to:

- ACKNOWLEDGE that the preservation of nature and nature processes is a major global service which has to be provided on an ongoing basis for the survival of the humanity;

- RECOGNISE that the 200 priority eco-regions of the world are capable of providing this service, and that the conservation of natural processes should be the main objective in the development of these regions, based on jointly agreed strategies;

- DEVELOP and implement payment schemes for the preservation of biological systems as a global service;

- ENSURE support from the world community to the regions that preserve the vital biological systems of the Planet;

- ENSURE a special favoured status for goods and services produced in a sustainable way in the 200 priority eco-regions.

We are committed to the elaboration of a strategy for sustainable development of the Altai-Sayan eco-region based on the above principles and on the Agreement between the Governments of the Russian Federation and Mongolia on Environmental Protection, and on the A greement of Co-operation in Nature Protection between the Republics of Altai, Khakassia and Tyva;

We hope that all people of the Planet will support AltaiSayan Millennium Initiative. Any country or region sharing these principles can join the Altai-Sayan Millennium Initiative by notifying the WWF R ussian Program Office that will act as a co-ordinating agency.

The Head of the Republic of Altai (Russia)

The Chairman of the Government of the Republic of Khakassia (Russia)

The President of the Republic of Tyva (Russia)

The Head of the Administration of the Altai Territory (Russia)

The Head of the Administration of Krasnoyarsky Territory (Russia)

The Governor of Bayan-Ulgii (Mongolia)

The Governor of Khovd (Mongolia)

The Governor of Khuvsugul (Mongolia)

The Governor of Uvs (Mongolia)

The Director of WWF Russian Program Office

The Director of the WWF Mongolian Project Office 